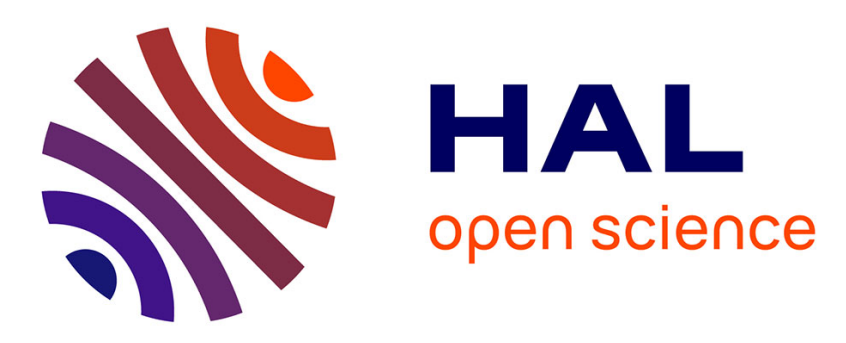

\title{
LOW SEROPREVALENCE OF SYPHILIS IN BURKINA FASO
}

Fati Kirakoya-Samadoulougou, Marie-Christine Defer, Seydou Yaro, Paulin

Fao, François Ilboudo, Youssouf Langani, Nicolas Meda, Annie Robert, Nicolas Nagot

\section{To cite this version:}

Fati Kirakoya-Samadoulougou, Marie-Christine Defer, Seydou Yaro, Paulin Fao, François Ilboudo, et al.. LOW SEROPREVALENCE OF SYPHILIS IN BURKINA FASO. Sexually Transmitted Infections, 2010, 87 (1), pp.35. 10.1136/sti.2010.042465 . hal-00556862

\section{HAL Id: hal-00556862 https://hal.science/hal-00556862}

Submitted on 18 Jan 2011

HAL is a multi-disciplinary open access archive for the deposit and dissemination of scientific research documents, whether they are published or not. The documents may come from teaching and research institutions in France or abroad, or from public or private research centers.
L'archive ouverte pluridisciplinaire HAL, est destinée au dépôt et à la diffusion de documents scientifiques de niveau recherche, publiés ou non, émanant des établissements d'enseignement et de recherche français ou étrangers, des laboratoires publics ou privés. 


\section{LOW SEROPREVALENCE OF SYPHILIS IN BURKINA FASO}

Fati Kirakoya-Samadoulougou ${ }^{1,2}$, Marie-Christine Defer $^{2}$, Seydou Yaro $^{2}$, Paulin Fao $^{2}$, François Ilboudo ${ }^{3}$, Youssouf Langani ${ }^{3}$, Nicolas Meda ${ }^{2,4}$, Annie Robert ${ }^{1}$ and Nicolas Nagot $^{5}$

${ }^{1}$ Pôle Epidémiologie et Biostatistique, Institut de recherche expérimentale et clinique (IREC), Faculté de Santé Publique, Université catholique de Louvain, Bruxelles, Belgique.

${ }^{2}$ Centre Muraz, Bobo-Dioulasso, Burkina Faso.

${ }^{3}$ Institut National de la statistique et de la démographie, Ouagadougou, Burkina Faso.

${ }^{4}$ Département de santé publique, Université de Ouagadougou, Burkina Faso

${ }^{5}$ Université Montpellier 1, EA 4205 “transmission, Pathogenèse et prévention de l'infection par le VIH”, Montpellier, France.

Part of the contents of this manuscript was presented at the $5^{\text {th }}$ International AIDS Society conference on HIV pathogenesis, treatment and prevention, Cape Town (South Africa), 19 - 22 July, 2009.

Article type : short reports

Word count : 774

\section{Corresponding author:}

Fati KIRAKOYA-SAMADOULOUGOU, EPID, Clos

Chapelle-aux-Champs, 30, Boîte 30.58, 1200 Bruxelles, Belgique

Phone: (+32) 0276438 26, Fax: (+32) 027643328

Email: fati.kirakoya@uclouvain.be 


\section{Specific tasks and major degree(s) of author and co-authors:}

Seydou Yaro (MD, Msc), Paulin Fao (MD, Msc), and Nicolas Nagot (MD, PhD) designed the study, directed its implementation, coordinated the discussion of the results, and commented on the draft manuscript.

Fati Kirakoya-Samadoulougou (Msc) performed serological testing, retrieved the data, and participated in the statistical analysis and the data interpretation and manuscript preparation.

François Ilboudo(Msc) and Youssouf Langani (Msc) coordinated data collection in Ouagadougou site, and commented on the draft manuscript.

Marie-Christine Defer (PhD) implemented, performed and supervised all laboratory activities including quality assurance and control, participated in the interpretation of results, and corrected the first draft.

Nicolas Meda (MD, PhD) helped supervise the field activities, designed the study's analytic strategy and manuscript preparation.

Annie Robert (PhD) provided guidance to all aspects of statistical analysis and revised manuscript for important intellectual content.

All authors read and approved final manuscript. 


\section{Abstract:}

Background: Little information is available on the epidemiology of syphilis in West Africa, where this infection is routinely screened in antenatal clinics to prevent congenital infection. In order to inform control programmes, we estimated the burden of active syphilis among pregnant women and adults in Burkina Faso.

Methods: This study enrolled 2136 pregnant women from 98 health care facilities and 1679 consenting women and men from the general population of Ouagadougou, the capital city. After a face-to-face interview on demographic characteristics, blood samples were collected and tested for syphilis. Active syphilis was defined by a dually positive result on RPR and TPHA tests.

Results: The overall seroprevalence of active syphilis was $1.7 \%$ (95\% confidence interval $(C I)=1.3-2.2)$, with similar rates between women $(1.2 \%, C I=0.7-2.3)$ and men $(1.8 \%, C I=1.0-$ 3.0) in Ouagadougou, and a trend for higher prevalence among pregnant women from semiurban areas $(2.2 \%, \mathrm{CI}=1.0-4.5)$ compared with rural areas $(1.7 \%, \mathrm{CI}=1.2-2.4, \mathrm{p}=0.06)$. The prevalence tended to be higher among women aged 20-24 (2.6\%, CI=1.3-7.6) and men aged 30-34 (3.9\%, CI=0.8-11.0) than at other ages. However, age, marital status, location and education were not associated with syphilis.

Conclusion: The low prevalence of syphilis among pregnant women and the adult general population is very encouraging but should not challenge the amount of resources dedicated to STI and HIV prevention.

Key words: Syphilis, urban, rural, prevalence, Burkina Faso 


\section{Introduction}

Syphilis remains a major cause of reproductive morbidity and poor pregnancy outcomes in sub-Saharan Africa, which justified a routine serological screening during antenatal consultations. In addition, syphilis infection substantially increases the sexual transmission of $\operatorname{HIV}(1)$.

The prevalence of syphilis amongst pregnant women varies widely throughout Africa, from 17.4\% in Cameroon, $8.4 \%$ in South Africa to $6.7 \%$ in Central African Republic (2). In Burkina Faso (BF), the syphilis prevalence among pregnant women was $0.24 \%$ between 1995 and 1998 (3). In the general population, only 3 cases of syphilis have been detected among a random sample of 2364 adults in 2000(4). .

In order to document syphilis prevalence in BF, we conducted a cross-sectional study among the general population in the capital city and among pregnant women in 4 geographically distant provinces of $\mathrm{BF}$.

\section{Methods}

\section{Study among pregnant women}

A sero-survey was conducted between May and July 2003 among pregnant women attending all ANC clinics $(\mathrm{n}=98)$ from Boulgou, Poni, Seno and Yatenga provinces(5).

\section{Study in the general population in Ouagadougou, capital city}

We used a two-stage clustered sample design in the first stage, we randomly selected 59/713 administrative areas and in the second stage, we randomly selected 20 households in each area. All adults aged 15-49 years present in the selected households were invited to participate in the study. After informed consent, individuals were interviewed to collect data on demographic factors, medical backgrounds and behaviours related to the risk of HIV/STI. 


\section{Common procedures for the two studies}

Active serological syphilis was diagnosed by a positive Rapid plasma regain (RPR) test (any titre), confirmed by the Treponema haemaglutination assay test (TPHA; at dilution below 1:80) (Newmarket Laboratories Ltd Germany). Prevalences are reported with 95\% confidence intervals computed using Poisson distribution because of small proportions. All analyses (estimation, confidence intervals), adjusted for the Ouagadougou clustered design. Specially, we specified individual weight, secondary sampling units and primary sampling unit (6). A $P$ value $<0.05$ was considered as significant.

\section{Ethical considerations}

The Ministry of Health of BF approved the study. Participants with active syphilis and their partners were treated based on the National STD Treatment Guidelines. Because HIV test results unlinked, women and men who wished to know their HIV status were referred to a nearby facility for free voluntary counselling and testing.

\section{Results}

The seroprevalence of syphilis was $1.7 \%(95 \%$ confidence interval $(\mathrm{CI})=1.3-2.2)$ among all participants $(\mathrm{N}=3815)$, with a good response rate $(93.5 \%$ among pregnant women and $77.2 \%$ in Ouagadougou).

A total of 64 pregnant women (3.0\%) were positive for RPR; 38 were positive for TPHA, giving a active syphilis seroprevalence of $1.8 \%(\mathrm{CI}=1.3-2.5)$, ranging from $0.6 \%(\mathrm{CI}=0.2-$ 1.9) in Boulgou province to 3.6\% $(\mathrm{CI}=2.2-5.9)$ in Poni province (table 1). Pregnant women living in rural areas tended to be less infected (1.7\% versus $2.2 \%)$ than those living in semiurban areas (main cities of the province) $(\mathrm{p}=0.06)$.

HIV prevalence in this population was $2.5 \%(\mathrm{CI}=1.9,3.3)$, ranging from $1.3 \%(\mathrm{CI}=0.5-2.9)$ in Seno province to $3.6 \%(\mathrm{CI}=2.2-5.7)$ in Boulgou province. 
In Ouagadougou, active syphilis seroprevalence was $1.5 \%(\mathrm{CI}=1.1-2.3)$. There were $32 \mathrm{RPR}$ positive and 25 TPHA positive. The prevalence of active syphilis tended to be higher among women aged 20-24 (2.6\%, CI=1.5-3.7) and men aged 30-34 (3.9\%, CI=0.4-8.2). However, age, marital status, location and education were not associated with syphilis in multivariable analysis (data not shown).

\section{Discussion}

The prevalence of syphilis among pregnant women in this study was lower than in a similar study from 1997 (2.5\%, IC:1.7\%-3.5\%) (7), but with important regional variations.

The syndromic management of STI was implemented in BF in 1996. Widespread use of antibiotics and good access to health care may have contributed to the decline in syphilis and STD prevalence(8), along with a decline in risky sexual behaviours resulting from HIV prevention programmes.

The differences in syphilis prevalence between urban (Ouagadougou) and rural areas (pregnant women) may be explained by different sexual behaviours, the urban area being more exposed to HIV prevention programmes. The development of HIV prevention initiatives towards rural areas could be pivotal to further reduce syphilis.

This low prevalence of syphilis infection should not challenge the systematic screening of this infection among pregnant women. Terris-Prestholt and colleagues (9) estimated the cost effectiveness of the intervention according to different levels of syphilis prevalence varying from $2 \%$ to $15 \%$. The cost per DALY saved decreased substantially as prevalence increased. However, even at prevalence as low as $2 \%$, antenatal syphilis screening and treatment remains cost effective (\$33 per DALY saved including stillbirth).

The low prevalence of syphilis in Burkina Faso is encouraging, but should not divert the resources dedicated to STI and HIV prevention in the country to other interventions. 


\section{References}

1. Fleming DT, Wasserheit JN. From epidemiological synergy to public health policy and practice: the contribution of other sexually transmitted diseases to sexual transmission of HIV infection. Sex Transm Infect 1999; 75:3-17.

2. World Health Organization. Global Prevalence and Incidence of Selected Curable Sexually Transmitted Infections: Overview and Estimates. 2001.

3. Sombie I, Meda N, Cartoux M et al. Seroprevalence of syphilis among women attending urban antenatal clinics in Burkina Faso, 1995-8. The DITRAME Study Group. DIminunation de la TRAnsmission Mere-Enfant. Sex Transm Infect 2000; 76:314-316.

4. Lagarde E, Congo Z, Meda $\mathrm{N}$ et al. Epidemiology of HIV infection in urban Burkina Faso. Int J STD AIDS 2004; 15:395-402.

5. Kirakoya-Samadoulougou F, Nagot N, Defer MC et al. Bacterial vaginosis among pregnant women in Burkina Faso. Sex Transm Dis 2008; 35:985-989.

6. Levy SP, Lemshow S. Sampling of Populations: Methods and Applications. Wiley 4th edition. 2008.

7. Sangare L, Meda N, Lankoande S et al. HIV infection among pregnant women in Burkina Faso: a nationwide serosurvey. Int J STD AIDS 1997; 8:646-651.

8. Nagot N, Meda N, Ouangre A et al. Review of STI and HIV epidemiological data from 1990 to 2001 in urban Burkina Faso: implications for STI and HIV control. Sex Transm Infect 2004; 80:124-129.

9. Terris-Prestholt F, Watson-Jones D, Mugeye K et al. Is antenatal syphilis screening still cost effective in sub-Saharan Africa. Sex Transm Infect 2003; 79:375-381. 
Table 1: Demographic variation of the syphilis prevalence in pregnant women and the general population of Burkina Faso.

\begin{tabular}{|c|c|c|c|c|c|c|}
\hline & \multicolumn{2}{|c|}{ Pregnant-women } & \multicolumn{4}{|c|}{ General population } \\
\hline & \multirow[b]{2}{*}{ no } & \multirow[b]{2}{*}{$\begin{array}{l}\text { Prevalence }(\%) \\
\text { and } 95 \% \text { CI }\end{array}$} & \multicolumn{2}{|r|}{ Men } & \multicolumn{2}{|r|}{ Women } \\
\hline & & & No & $\begin{array}{c}\text { Prevalence }(\%) \\
\text { and } 95 \% \text { CI }\end{array}$ & no & $\begin{array}{c}\text { Prevalence }(\%) \\
\text { and } 95 \% \mathrm{CI}\end{array}$ \\
\hline \multicolumn{7}{|l|}{ Age } \\
\hline $15-19$ & 460 & $1.1(0.4-2.7)$ & 193 & $1.6(0.3-4.5)$ & 260 & $0.8(0.1-2.8)$ \\
\hline $20-24$ & 636 & $2.4(1.4-4.0)$ & 210 & $1.4(0.3-4.1)$ & 169 & $3.6(1.3-7.6)$ \\
\hline $25-29$ & 472 & $1.7(0.8-3.4)$ & 150 & $2.7(0.7-6.7)$ & 143 & $0.0(0.0-2.5)$ \\
\hline $30-34$ & 288 & $2.4(1.0-4.9)$ & 77 & $3.9(0.8-11.0)$ & 107 & $0.9(0.0-5.1)$ \\
\hline$\geq 35$ & 280 & $1.1(0.2-3.1)$ & 163 & $0.6(0.0-3.4)$ & 207 & $1.0(0.1-3.4)$ \\
\hline \multicolumn{7}{|l|}{ Marital status } \\
\hline Single & 56 & $0.0(0.0-6.4)$ & 527 & $1.7(0.8-3.3)$ & 338 & $0.9(0.2-2.8)$ \\
\hline Married/living together & 2068 & $1.8(1.3-2.5)$ & 266 & $1.9(0.6-4.3)$ & 548 & $1.5(0.7-3.0)$ \\
\hline \multicolumn{7}{|l|}{ Have been to school } \\
\hline Yes & 414 & $1.0(0.3-2.6)$ & 645 & $1.7(0.9-3.1)$ & 540 & $1.1(0.5-2.5)$ \\
\hline No & 1722 & $2.0(1.4-2.8)$ & 148 & $2.0(0.4-5.8)$ & 346 & $1.4(0.5-3.5)$ \\
\hline \multicolumn{7}{|l|}{ Localisation } \\
\hline Ouagadougou & ------ & ------- & 793 & $1.8(1.0-3.0)$ & 886 & $1.2(0.7-2.3)$ \\
\hline Rural & 1777 & $1.7(1.2-2.4)$ & ----- & --------- & ----- & ----------- \\
\hline Semi-Urban & 359 & $2.2(1.0-4.5)$ & ----- & --------- & ----- & ----------- \\
\hline
\end{tabular}




\section{Key points}

- Although the seroprevalence of active syphilis was as low as $2 \%$ among pregnant women in Burkina Faso, it still justifies the need for systematic screening during pregnancy.

- Age, marital status, urban or rural location and education were not associated with active syphilis. Pregnant women from semi-urban areas tended to be more infected with syphilis than pregnant women from rural areas

- this survey confirm the decrease of bacterial STIs in this African region over the past 15 years.

\section{Acknowledgements}

These results were presented in part at the 5th International AIDS Society conference on HIV pathogenesis, treatment and prevention, Cape Town (South Africa), 19 - 22 July, 2009.

We thank the staff from the 4 provinces of Burkina Faso, the staff of centre MURAZ, the Ministry of Health, and the National AIDS Control Programme.

This work was supported by the United Nations Development Programme (UNDP), World Health Organisation (WHO), the United Nations Population Fund (UNFPA), Embassies of Holland, Switzerland, Denmark and Belgium.

Finally, we thank all the individuals who sacrificed their time to be interviewed as part of this study.

Conflict of interest : none

Word count : 774 


\section{Copyright licence statement}

I Fati KIRAKOYA-SAMADOULOUGOU The Corresponding Author has the right to grant on behalf of all authors and does grant on behalf of all authors, an exclusive licence on a worldwide basis to the BMJ Group and co-owners or contracting owning societies (where published by the BMJ Group on their behalf), and its Licensees to permit this article (if accepted) to be published in Sexually Transmitted Infections (STI) and any other BMJ Group products and to exploit all subsidiary rights, as set out in your licence set out at http://sti.bmj.com//ifora/licence.pdf). 